\title{
TRADISI BAU NYALE TERHADAP NILAI MULTIKULTURAL PADA SUKU SASAK
}

\author{
Runi Fazalani \\ 201710550211012 \\ Magister Pendidikan Bahasa Indonesia \\ Program Pascasarjana \\ Universitas Muhammadiyah Malang \\ Email: runifazalani3@gmail.com
}

\begin{abstract}
ABSTRAK
Penelitian ini bertujuan untuk menjelaskan tentang: (1) Pengaruh dan fungsi tradisi Bau Nyale terhadap masyarakat Suku Sasak di Pulau Lombok, (2) Nilai-nilai budaya yang terkandung dalam tradisi Bau Nyale. Penelitian ini menggunakan metode deskriptif kualitatif yaitu mengeksplorasi tradisi budaya yang mampu mempengaruhi masyarakat terhadap nilai-nilai budaya yang telah ada dalam tradisi Bau Nyale di Suku Sasak Pulau Lombok. Obyek penelitian ini adalah tradisi Bau Nyale di Pantai Segar Desa Kute Kecamatan Pujut Kabupaten Lombok Tengah NTB. Hasil penelitian ini menunjukkan tentang 1) Beberapa fungsi Tradisi Bau Nyale terhadapa masyarakat Suku Sasak sebagai berikut: (1) fungsi historis, (2) sebagai rekreasi, (3) sebagai even pariwisata, (4) sebagai wadah ekspresi nilai budaya, (5) sebagai penggerak ekonomi masyarakat, (6) sebagai enkultarisi budaya. 2) Nilai-nilai budaya yang terkandung dalam Bau Nyale sebagai berikut: (1) Nilai Spiritual atau Nilai Ketuhanan, (2) Nilai Integrasi atau sebuah pembaharuan, dan (3) Nilai Solidaritas.
\end{abstract}

Kata Kunci: Tradisi Bau Nyale dan Nilai Multikultural

\section{ABSTRACT}

This is of perpouse research to explain about: (1) the influence and function of the smell of this Nyale on the Sasak people in the Lombok Island, (2) the cultural values in the contained tradition of the smell of Nyale. Using the descriptive qualitative method is the explore be cultural traditions thet are be able to influence the community towards cultural the values has been in the tration smell Nyale in the Segar beach kute village 
FON ; Jurnal Pendidikan Bahasa dan Sastra Indonesia

Volume 13 Nomor 2 Tahun 2018

subdistrict of Pujut Central Lombok Regency. The study of result show about: 1) some functions of the tradition of the smell of Nyale to the Sasak people tribe of communityas follows are: (1) historical function, (2) the as recreation, (3) the as a tourism event, (4) the countainer for expressing in the cultural values, (5) the economic driver of the community, (6) the cultural enculturation. 2) cultural values sometimes in the smell of Nyale as follows: (1) the spiritual value or the deity value, (2) the integration value or a renewal, (3) the solidarity value.

Keywords: The tradition of the smell of Nyale and multicultural value

\section{PENDAHULUAN}

Tradisi kehidupan pada suatu daerah terhadap nilai-nilai budaya yang terkandung di dalam multikultural pada Suku Sasak di Pulau Lombok sangat banyak. Tradisi atau fenomena yang telah berlangsung dari abad XVI telah mengalami perubahan semenjak masuknya agama Islam. Semenjak abad itu agama Islam berkembang dengan pesat. Agama Islam pada abad XIII sudah masuk ke Pulau Lombok oleh seorang raja muslim yang berasal dari Jawa. Meskipun di Pulau Lombok sudah di masuki agama Islam akan tetapi kebanyakan mereka sering kali mencampur adukkan antara agama Islam dan non-Islam dikarenakan masyarakat Lombok belum paham dengan perbedaan masing-masing agama (Budiwanti, 2000: 9). Adapun kepercayaan yang di anut oleh masyarakat Pulau Lombok sebelum agama Islam masuk, yaitu Hindu-Budhis dan Sasak Boda yang sudah ada sejak abad VII terlebih dahulu masuk ke Pulau Lombok.

Pada zaman dahulu pengaruh agama, Islam, Hindu, Budha, Kristen, dan Konghucu membuat kepercayaan masyarakat Suku Sasak di Pulau Lombok cukup beragam. Sebelum pengaruh dari agama-agama tersebut, Pulau Lombok telah mengenal kepercayaan Boda dengan sebutan Sasak-Boda. Sasak-Boda tidak sama dengan Budhisme. Adapun yang menandai Sasak-Boda adalah dengan adanya panteisme dan animisme. Di samping itu karena adanya pemujaan dan kepercayaan terhadap leluhur seperti dewa lokal dan lainnya yang merupakan fokus utama yang dianut dalam kepercayaan masyarakat Suku Sasak di Pulau Lombook. Pencampuran dalam keyakinan ini masih berlaanjut, terlihat jelas pada saat agama Hindu seiring berjalannya 
FON ; Jurnal Pendidikan Bahasa dan Sastra Indonesia Volume 13 Nomor 2 Tahun 2018

penaklukkan kerajaan Makassar- pemahaman, dan penilaian terhadap Lombokoleh kerajaan Karangasem Bali. budaya seseorang dan suatu keingintahuan Pada akhirnya pengaruh agama Hindu tentang budaya lain. Dalam hal ini lebih semakin kuat. Oleh sebab itu jangan heran tepatnya kepenilaian budaya-budaya yang pada waktu tertentu masyarakat Suku berbeda-beda. Sedangkan menurut Parekh Sasak di Pulau Lombok identik dengan (1997) multikulturalisme adalah Hinduisme. Tradisi atau fenomena yang sekelompok masyarakat yang terdiri dari bernafaskan agama Hindu misalnya di beberapa macam komunitas budaya ibukota Nusa Tenggara Barat dan Lombok dengan segala kelebihan yang dimiliki Tengah khususnya di pantai selatan Suku oleh masing-masing, dengan sedikit Sasak di Pulau Lombok keduanya perbedaan konsepsi masalah dunia, suatu memiliki jalinan yang sangat erat. sistem arti, bentuk organisasi sosial, nilai, Menurut Purna (2003) memaparkan bahwa tradisi atau fenomena antara unsur agama Hindu dan Islam pada Suku Sasak di Pulau Lombok disebut Sinkretisme, merupakan perpaduan antara dua atau lebih religi untuk mencari keseimbangan, keserasian, dan kedamaian hati.

Adapun tradisi yang dianggap menyimpang sekelompok masyarakat dan sangat sulit dihapuskan sampai zaman yang modern ini. Jadi sangat penting pemahaman tentang pandangan adat, sejarah, dan kebiasaan suatu kelompok.

Tradisi Bau Nyale berasal dari bahasa Sasak. Dalam bahasa Sasak, Bau artinya menangkap sedangkan Nyale merupakan nama sejenis cacing laut. Jadi sesuai namanya, tradisi ini kegiatan menangkap Nyale yang ada di laut. Tradisi Bau Nyale merupakan sebuah kegiatan yang dihubung-hubungkan dengan kebudayaan setempat. Bau Nyale berawal dari legenda lokal yang multikultural suatu masyarakat. Adapun melatarbelakangi yakni tentang kisah multikultural merupakan keragaman seorang Putri Mandalike. Menurut budaya, yang di mana suatu individu hidup di antara kelompok yang satu dengan kelompok sosial yang lain dengan memiliki kebiasaan yang berbeda-beda. Menurut Blum (2001) multikulturalisme kepercayaan masyarakat Lombok, nyale konon merupakan jelmaan Putri Mandalike. Putri Mandalike dikisahkan sebagai putri yang cantik dan baik budi pekertinya. Karena kecantikan dan meliputi sebuah penghargaan,

kebaikannya, banyak raja dan pangeran 
FON ; Jurnal Pendidikan Bahasa dan Sastra Indonesia

Volume 13 Nomor 2 Tahun 2018

yang jatuh cinta kepadanya dan ingin dan nilai-nilai budaya apa saja yang menjadikannya sebagai permaisuri. Putri terkandung dalam tradisi Bau Nyale di tersebut bingung dan tidak bisa Suku Sasak Pulau Lombok.

menentukan pilihannya, dia sangat bingung. Jika dia memilih salah satu dari mereka, dia takut akan terjadi peperangan. Oleh sebab itulah, putri pun lebih memilih mengorbankan dirinya dengan menceburkan dirinya ke laut dan berubah menjadi nyale yang berwarna-warni. Oleh 6 sebab itu, masyarakat di sini percaya bahwa Nyale tidak hanya sekedar cacing laut biasa tetapi merupakan makhluk yang dipercaya dapat membawa kesejahteraan bagi yang menang-kapnya.

Nilai-nilai budaya merupakan nilai yang telah disepakati dan sudah tertanam dalam suatu masyarakat, lingkup organisasi, lingkungan masyarakat, yang mengakar pada suatu kepercayaan (beleive), kebiasaan, simbol-simbol, dengan karakteristik tertentu yang dapat dibedakan satu dan lainnya sebagai acuan prilaku dan tanggapan atas apa yang akan terjadi atau sedang terjadi (Budi Agus Riswandi dan Syamsudin, 2005: 39-40)

Berdasarkan paparan di atas peneliti dapat merumuskan masalah yang harus di jawab yaitu bagaimanakah pengaruh dan fungsi tradisi Bau Nyale terhadap masyarakat Suku Sasak di Pulau Lombok

\section{METODE}

Pendekatan yang digunakan adalah pendekatan multikultural. Pendekatan multikultural dipilih karena pendekatan ini berangkat dari suatu keadaan yang baru, yaitu keberadaan dua atau lebih kebudayaan yang berbeda yang hidup berdampingan dan sebuah pendekatan yang mengakui keberagaman budaya yang ada. Penelitian ini difokuskan kepada nilai-nilai budaya yang ada pada masyarakat. Metode penelitian yang digunakan yaitu deskriptif kualitatif yaitu mengeksplorasi tradisi budaya yang mampu mempengaruhi masyarakat terhadap nilai-nilai budaya yang telah ada dalam tradisi Bau Nyale di Suku Sasak Pulau Lombok. Obyek penelitian adalah tradisi Bau Nyale di Pantai Segar Desa Kute Kecamatan Pujut Kabupaten Lombok Tengah NTB. Pengumpulan data melalui wawancara dan observasi selama acara berlangsung, studi pustaka dari hasil penelitian yang sejenis di perpustakaan daerah Nusa Tenggara Barat dan jurnal yang berhubungan dengan budaya. 


\section{HASIL PENELITIAN DAN Gambar 1: Pantai kuta, Lombok tengah PEMBAHASAN \\ Fungsi tradisi Bau Nyale terhadap \\ Pengaruh Dan Fungsi Tradisi Bau masyarakat Suku Sasak Lombok Tengah Nyale Terhadap Masyarakat Suku yaitu sebagai berikut:}

\section{Sasak Di Pulau Lombok}

Pengaruh dan fungsi tradisi Bau Nyale terhadap masyarakat terutama masyarakat Sasak yang tinggal di pesisir pantai selatan tepatnya di pantai kuta, adapun pengaruh tradisi Bau Nyale yang dapat mempengaruhi masyarakat setelah menangkap Nyale seperti dapat menambah perekonomian masyarakat, dapat di makan, upaca kesuburan tanah pertanian, dan di jual. selalu menyelenggarakan tradisi tersebut secara sistematis. Dalam secara sistematis yang dimaksudkan adalah melakukan acara rapat warga, acara yang di bahas dalam rapat tersebut yaitu membahas tentang firasat yang dirasakan oleh pemangku. Penentuan waktu yang tepat dengan merujuk pada tanda-tanda alam, peristiwa atau bahkan kejadian yang terjadi di masyarakat dan siapa saja orang yang akan dilibatkan dalam acara tersebut.

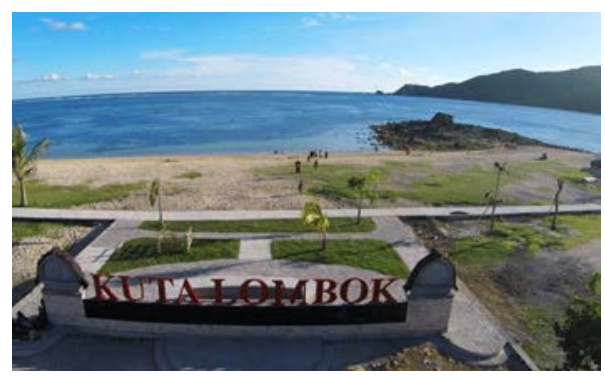

\section{Fungsi Historis}

Dalam tradisi Bau Nyale mengajak seluruh masyarakat Lombok untuk mengenang dan menghargai kembali sejarah para leluhur dan para pemimpin lainnya yang sudah berjasa terhadap tradisi Bau Nyale. Dalam tradisi Bau Nyale diselenggarakan sebuah drama kolosal Putri Mandalike yang sudah diperlihatkan sejak pertama kali di pertunjukkan. Bahwa masyarakat Suku Sasak meyakini bahwa Nyale itu berasal dari Putri Mandalike. Putri Mandalike merupakan seorang tokoh sentral dan tokoh figur yang rela mengorbankan dirinya sendiri untuk kesejahteraan masyarakat Lombok. Tradisi Bau Nyale itu di selenggarakan setiap tanggal 19 dan 20 pada bulan sepuluh dan tepatnya di pantai selatan kuta.

\section{Fungsi Rekreasi}

Penangkapan Nyale selalu bertepatan dengan selesai menanam padi di sawah. Pekerjaan masyarakat di rumah maupun di sawah sudah kosong. Menangkap Nyale atau Bau Nyale bagi masyarakat memiliki 
makna dan arti tersendiri karena mereka dapat melepaskan rasa lelah yang selama ini mereka pikul. Menurut informasi para karma adat bahwa pada zaman dahulu sebelum masuknya aliran listrik ke desa. Pemuda dan pemudi menyalakan api unggun dengan obor dan didampingi oleh orang tua masing-masing, kemudian pemuda pemudi melakukan sahut-sahutan dengan pantun dan isi pantunnya masih dengan batas kesopanan. Hal itu merupakan hiburan menarik untuk masyarakat Lombok. Bahkan pada tahun-tahun ini perayaan tradisi bau nyale di hadiri oleh turisturis manca Negara yang cukup banyak, sehingga suasana dalam perayaan tradisi Bau Nyale orangorang seperti berada dalam pasar malam.

\section{Sebagai Event Pariwisata}

Masyarakat Suku Sasak di Lombok Tengah bagian selatan tepatnya di pantai kuta, dulu masyarakat di sana tidak pernah berpikir tentang tradis Bau Nyale yang mereka lakukan akan menjadi demikian terkenalnya. Masyarakat melakukannya karena hanya sebagai perwujudan rasa bakti kepadda leluhurnya dan kepercayaan yang telah tertanam dalam diri mereka yang telah di yakini. Mereka meyakini bahwa tradisi Bau Nyale berpengaruh kepada keselamatan , keberhasilan panen, kesejahteraan hidup, dan menyambut Putri Mandalike. Adapun pengaruh lain yang dapat mempengaruhi masyarakat misalnya setelah menangkap Nyale seperti dapat menambah perekonomian masyarakat, dapat di makan, upaca kesuburan tanah pertanian, dan di jual.

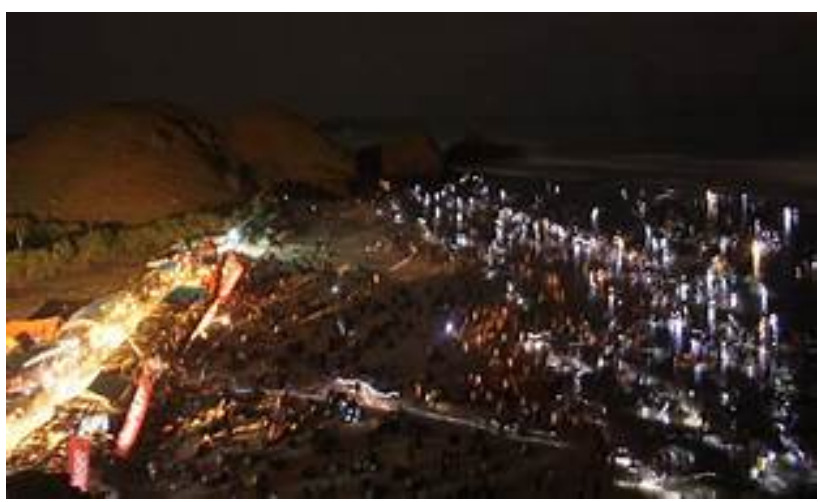

Gambar 2: Perayaan Bau Nyale sekitar pukul 2 pagi

\section{Sebagai Wadah Ekspresi Nilai Budaya}

Tradisi Bau Nyale telah memiliki nilai budaya yang telah memberikan identitas pada Suku Sasak pada umumnya dan khusunya kaum perempuan. Adapun nilai-nilai budaya yang terdapat dalam tradisi Bau nyale dan yang terkandung dalam mitos Putri Mandalike sebagai berikut: 
(1) nilai spiritual atau nilai ketuhanan,

(2) nilai solidaritas, (3) nilai emansipasi, (4) nilai pengorbanan, (5) nilai keadilan, (6) nilai kebesaran, dan (7) nilai patriotism ( Yakum, 2009).

\section{Sebagai Penggerak Ekonomi Masyarakat}

Bau Nyale atau penangkapan Nyale membutuhkan waktu sekitar dua jam bahkan lebih untuk awalnya saja, akan tetapi sebelum puncak penagkapan Nyale terhitung lama dan masyarakat mebutuhkan waktu untuk begadang. Pada saat itu lah pedagangpedagang berjejeran di pinggir pantai dan gerakan ekonomi pada saat Bau Nyale sangat tinggi karena yang hadir dalam tradisi Bau Nyale itu melebihi ratusan orang. Tidak mungkin jika semua orang yang hadir tidak membeli sesuatu yang dapat di makan.

\section{Sebagai Wadah Enkulturasi Budaya}

Masyarakat yang hadir dalam tradisi Bau Nyale bukanlah orang Kute atau orang Kecamatan Pujut saja akan tetapi orang yang datang dari berbagai kecamatan lain, bahkan orang yang berasal dari kota Mataram. Kedatangan mereka kesana hanya sebagai penonton dan menyaksikan segala acara tradisitradisional yang ada disana baik dari cara berpakair sikap, dan perkataannya dapat memberikan pengaruh atau sebaliknya. Secara tidak langsung tradisi yang di anut menjadi sebuah proses enkulturasi karena yang hadir dalam acara tersebut bukanlah orang dewasa saja akan tetapi anak kecil juga. Dalam hal ini proses enkulturasi dapat diajarkan tentang bagaimana bersabar dalam menunggu Nyale keluar dan dapat digunakan sebagai pementasan drama tentang kisah Putri Mandalika.

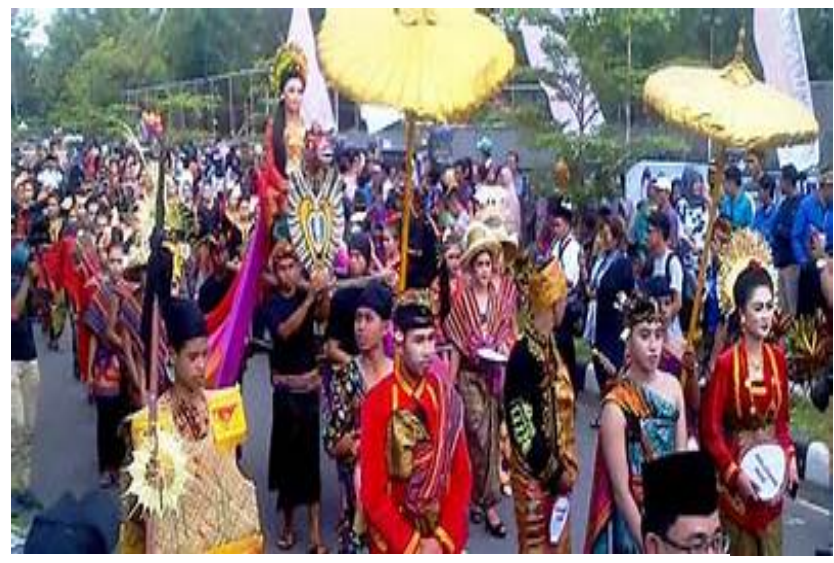

Gambar 3: Acara Karnaval Perayaan Bau Nyale

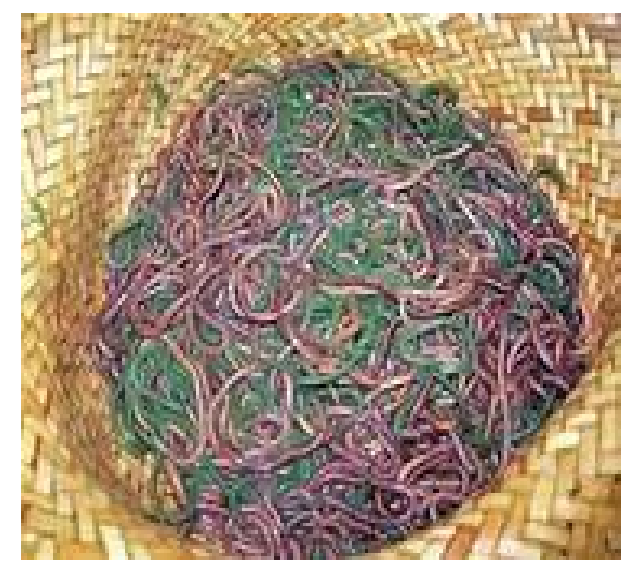

Gambar 4: Hasil Tangkapan Nyale 


\section{Nilai-nilai Budaya yang Terkandung} dalam Tradisi Bau Nyale

Masyarakat Suku Sasak telah memperkuat tradisi Bau Nyale dengan memberikan nilai-nilai budaya, yaitu harapan masyarakat Suku Sasak tentang hal-hal yang lebih baik dan sesuatu yang dapat diagungkan oleh sebagian besar anggota masyarakat Lombok sebagai suatu sistem etika. Sistem etika yang dimakaksud tersebut dijadikan sebagai pola bagi sasaran yang akan dituju ataupun merupakan acuan untuk mewujudkan tindakan bagi individu masyarakat Lombok. Nilai-nilai budaya dapat diartikan sebagai "pendapatpendapat” atau “pandangan-pandangan” yang digunakan oleh masyarakat Suku Sasak untuk menilai, menentukan baikburuknya, bermamfaat atau tidaknya sebuah peristiwa yang ada dalam sebuah fenomena kehidupan sebuah masyarakat (Ahimsa Putra, 2006).

Nilai-nilai budaya yang ada di Bau Nyale dapat dijadikan alat ukur, alat penilai yang terkandung dalam sistem pengetahuan budaya Suku Sasak. Adapun nilai budaya yang terkandung dalam tradisi Bau Nyale juga seperti kisah kesabaran, pengorbanan karena Putri Mandalike yang rela mengorbankan dirinya untuk kesejahteraan masyarakat, nilai moral seperti ini harus ditanamkan kepada seluruh masyarakat Lombok karena berkembangnya zaman sekarang ini mengakibatkan terkikisnya keberpihakan terhadap nilai-nilai moral, akibat dari cara berfikir yang rasionalistikmaterialistik. Segala sesuatu dalam hidup ini diukur hanya sebatas materi, sehingga nilai-nilai moral seperti tolong menolong, gotong royong, dan kebersamaan seakan memudar. Menurut Suarsana (2001) mengungkapkan nilai budaya yang terkandung dalam tradisi Bau Nyale yaitu sebagai berikut: (1) Nilai Spiritual atau Nilai Ketuhanan, (2) Nilai Integrasi atau sebuah pembaharuan, dan (3) Nilai Solidaritas.

Nilai-nilai budaya yang terkandung dalam tradisi Bau Nyale yang telah terkandung dalam Putri Mandalike telah di buat naskah Lontar Sasak seperti: (1) Naskah Lontar Kotaragama, naskah ini lebih kepada mengamanatkan bahwa bagi seorang permpuan yang memiliki keperibadian yang utuh, memiliki sopan santun, dan selalu berbuat baik kepada semua orang. (2) Naskah Lontar Rengganis, mengamanatkan tentang seseorang perempuan tidak boleh mankir dari janji-janjinya, (3) Naskah Lontar Megantara, mengamanatkan bahwa Permpuan Sasak harus pemberani dan 
FON ; Jurnal Pendidikan Bahasa dan Sastra Indonesia

Volume 13 Nomor 2 Tahun 2018

harus selalu setia kepada suaminya, dan diberikan pengakuan yang sama disiplin dan tegas (Wirata, 2016: 264- dengan tradisi-tradisi yang ada di 269).

\section{PENUTUP}

\section{Simpulan}

Berdasarkan hasil penelitian dan pembahasan di atas mengenai "Tradisi Bau Nyale Terhadap Nilai Multicultural pada Suku Sasak ”. berdasarkan analisis yang telah dilakukan maka dalam penelitian ini dapat disimpulkan hasil dan saran sebagai berikut: 1) Beberapa fungsi Tradisi Bau Nyale terhadapa masyarakat Suku Sasak sebagai berikut: (1) fungsi historis, (2) sebagai rekreasi, (3) sebagai even pariwisata, (4) sebagai wadah ekspresi nilai budaya, (5) sebagai penggerak ekonomi masyarakat, (6) sebagai enkultarisi budaya. 2) Nilai-nilai budaya yang terkandung dalam Bau Nyale sebagai berikut: (1) Nilai Spiritual atau Nilai Ketuhanan, (2) Nilai Integrasi atau sebuah pembaharuan, dan (3) Nilai Solidaritas.

\section{Saran}

Atas dasar nilai budaya $B a$

Nyale sebebarnya harus berada sebagai budaya intangibel yang memiliki nilai multikulturalisme. Karena budaya Indonesia terutama di Lombok. Tradisi Bau Nyale dapat dijadikan sebagai rujukan identitas etnis Sasak. Supaya ingang Suku Sasak maka inget dengan tradisi Bau Nyale.

Dalam hidup budaya akan selalu berubah karena mengikuti berubahnya zaman, oleh sebab itu etnis budaya yang ada di semua daerah yang sering di sebut dengan "pinggiran” seharusnya harus lebih dikaji dan diteliti sebagai bahan kebijakan pelestarian. Terutama budaya yang takbenda yang memiliki muatan nilai multikultural dari enam agama yang ada di Negara ini. Karena budaya seperti ini dapat menjadi sebuah simpul penyatuan dan persatuan etnis, Bangsa dan Negara Kesatuan Republik Indonesia.

\section{Daftar Pustaka}

Budiwanti, Erni. 2000. Islam Sasak: Wetu Telu Versus Waktu Lima. Yogyakarta: LKiS

Purna, I Made. Sinkretisme Agama Hindu dan Islam pada Masyarakat Sasak di Lombok” dalam jurnal Penelitian intangibel dapat disetarakan, dihormati, 
FON ; Jurnal Pendidikan Bahasa dan Sastra Indonesia

Volume 13 Nomor 2 Tahun 2018

Sejarah dan Nilai Tradisional Edisi

Kesebelas Nomor 11/III/2003.

Blum, A Laurence. 2001. Antirarisme, Multikulturalisme, dan komunitas Antar Ras, Tiga Nilai yang Bersifat Mendidik bagi sebuah masyarakat Multikultural, dalam Larry May, dan Shari Colinn-Chobanian, Etika Terapan; Sebuah Pendekatan Multikultural. Terjemahan; Sinta Carolina dan Dadang Rusbiantoro. Yogyakarta: Tiara Wacana.

Suarsana, I Made. "Kajian Nilai-nilai Budaya pada Tradisi Bau Nyale di Lombok dalam Rangka Sosialisasi dan Integrasi” dalam Jurnal Jnana Budaya Media Informasi Sejarah, Sosial, dan Budaya Edisi Kelima No. 05/V/2001.

Wirata I Wayan. Perempuan dalam Cerita Naskah Islam Lokal (Suku Sasak) di Lombok (Pendekatan Sosiologi)” dalam Jurnal Mudra Pusat
Penerbitan LPPM ISI Denpasar Vol.

31 no. 2. Mei 2016.

Ahimsa-Putra, Heddy Sahri. 2006.

Strukturalisme Levi-Strauss Mitos

dan Karya Sastra. Yogyakarta:

Kepel Press.

Yakum, H.Moh. 2009. “Kisah Putri Mandalike Nyale, Cerita Rakyat Nusantara Suku Sasak”. Makalah.

Parekh. 1997. National Culture and Multiculturalism. In Kenneth Thompson (ed) Media and Cultural Regulation. London-Thousand Oaks, Calif: Sage Publications in association with the open University.

Budi Agus Riswandi dan M. Syamsudin, Hak Kekayaan Intelektual dan Budaya Hukum, Raja Grafindo Persada, Jakarta, 2005, hlm. 39-40. 